\title{
Problem Based Learning Approach in the Designing of E-content for Engineering Courses
}

\author{
Norazah Mohd Nordin ${ }^{1} \&$ S. Tamil Selvan Subramaniam ${ }^{2}$ \\ ${ }^{\mathbf{1}}$ Faculty of Education, National University of Malaysia, Bangi, Selangor, Malaysia \\ ${ }^{2}$ Faculty of Technical and Vocational Education, Tun Hussein Onn University of Malaysia, Parit Raja, Batu Pahat, \\ Johor, Malaysia \\ Correspondence: S. Tamil Selvan Subramaniam, Faculty of Technical and Vocational Education, Tun Hussein Onn \\ University of Malaysia, 86400 Parit Raja, Batu Pahat, Johor, Malaysia. Tel: 60-13-620-4916. E-mail: \\ tselvan@uthm.edu.my
}

Received: May 2, 2013 Accepted: June 18, 2013 Online Published: August 1, 2013

doi:10.5539/ass.v9n10p300 URL: http://dx.doi.org/10.5539/ass.v9n10p300

\begin{abstract}
In Malaysia, there is a growing recognition for innovative teaching and learning methods, such as Problem Based Learning (PBL), in engineering education in order to develop competence graduates. The development of Information and Communication Technology (ICT) in education has given new impetus to the instructor to improve the quality of education and to meet the current education of the 21 st century. The use of e-learning in teaching and learning $(\mathrm{T} \& \mathrm{~L})$ is seen an alternative to produce knowledge workers. The discussion of this paper will look at the development of ideas, concepts and findings of past studies on the use of online PBL. The outcome of this discussion will provide an overview of (i) the background of PBL, (ii) the development of PBL in engineering field, (iii) the application of online PBL approaches for engineering courses and (iv) the model and the characteristics of PBL. In conclusion, the outcome of the discussions found that e-content materials are required in the engineering field due to the lack of theoretical framework and engineering pedagogy as well as the best method of online PBL implementation in designing and developing e-content materials based on PBL.
\end{abstract}

Keywords: information and communication technology, problem-based learning, e-learning, e-content, engineering courses

\section{Introduction}

The development of Information and Communication Technology (ICT) in education has given new impetus to the instructor to improve the quality of education and to meet the current education of the 21 st century. The development of ICT is being more explored to make it appropriate for their strategies and educational goals. The use of e-learning in teaching and learning process ( $\mathrm{T} \& \mathrm{~L}$ ) is considered as an alternative in achieving the goals of education and to produce first-class human capital. This is in line with the knowledge-based economic development as important agenda that will have a huge impact on the country's education system, especially in order to produce knowledge workers. To create an active learning environment in e-learning, PBL approach is gradually gaining attention. This paper first describes the background of PBL and implementation of PBL in Malaysian context. Then, this paper provides the summary of review from several development of PBL in engineering field and the application of online PBL approaches for engineering courses and lastly the model and the characteristics of PBL also describes in this paper. Several local PBL pilot studies that conducted in Malaysia are also included.

\section{Problem Based Learning}

The problem based learning (PBL) is a teaching approach in which the concept of PBL involves learning through the process of understanding or problem-solving (Barrows \& Tamblyn, 1980; Hmelo-Silver, 2004; Tse \& Chan, 2003; Tseng et al., 2008). This approach was originally developed in the field of medicine in 1969 at McMaster University, Canada (Barrows \& Tamblyn, 1980) and later developed in various other fields such as business, law, engineering, and education. PBL approach actually resulted from concerns of many educators and researchers regarding the deficiencies and problems that exist in conventional learning which emphasizes more on the contents (Barrows, 1986, 1996; Barrows \& Tamblyn, 1980; Hmelo-Silver \& Barrows, 2006). According to Boud and Feletti 
(1998), the conventional approach is not only ineffective, but failed in developing the students who are able to make wise judgments and adapt to various aspects particularly knowledge, thinking and skills.

The main goal of PBL is to help develop a flexible knowledge (Ferreira \& Trudel, 2012; Hmelo-Silver, 2004; Hoffmann \& Ritchie, 1997), improve problem solving skills (Ferreira \& Trudel, 2012; Hmelo-Silver, 2004; Hoffmann \& Ritchie, 1997) and self-directed learning (Hmelo-Silver, 2004), collaborative skills (Hmelo-Silver, 2004) and enhance intrinsic motivation (Hmelo-Silver, 2004). This approach is also able to develop higher-order thinking skills such as creative thinking (Alias \& Solomon, 2012; Awang \& Ramly, 2008; Fauziah, 2011) and critical thinking (Sendag \& Ferhan Odabasi, 2009). The benefits of PBL approach in teaching and learning process are that students are more focused on learning activities and thus able to form a more meaningful learning (Hmelo-Silver, 2004; Murray \& Savin-Baden, 2000; Savin-Baden, 2000). The PBL approach has great potential to foster the learning of procedural knowledge to a higher level or students are deeply involved in the learning process (Murray \& Savin-Baden, 2000). In addition, the PBL approach can also help students to develop lifelong learning skills (Hmelo-Silver, 2004, 2012). This is because the PBL approach requires students to integrate knowledge and interdisciplinary skills to form opinions and build their own answers in the process of solving a problem (Hmelo-Silver \& Barrows, 2006; Hmelo-Silver \& Eberbach, 2012).

The development of PBL approach is not only popular among academics and researchers in institutions abroad; Malaysia has also experienced the effects of this approach. The PBL approach is carried out in various fields such as law studies in the International Islamic University (IIA), the field of medicine and health sciences in the University of Malaysia Sarawak (UNIMAS), the field of medicine in the National University of Malaysia (NUM), the field of nursing and health sciences in International Medical University, physics studies in University of Science Malaysia (USM), computer science and information technology in University of Malaya and the field of interactive multimedia in the Multimedia University. In the engineering field, this approach was conducted in the chemistry studies at the University of Technology Malaysia (Yusof et al., 2005), for engineering courses in University of Tun Hussein Onn Malaysia (Salleh et al., 2007) and for electrical and electronic engineering courses in Polytechnic Port Dickson (Krishnan \& Ruhizan, 2009). The engineering courses have also used PBL extensively in the T \& $\mathrm{L}$ to cultivate students' problem-solving process.

\section{PBL Approach in Engineering Courses}

The PBL approach actually started in the field medicine (Barrows \& Tamblyn, 1980). However, now the PBL approach is not limited to the medical field alone, but has spread to various areas (Yusuf et al., 2005). The engineering field is seen as a field that is abstract, challenging, requires scientific skills, critical and creative thinking skills and problem-solving skills (Hassan et al., 2004; Yusof et al., 2005). In accordance with the goals of PBL approach, which focuses on learning through problem solving, this research was conducted by choosing the field of engineering as the application domain of this study. The PBL approach was implemented in a variety of engineering fields such as mechanical engineering program at Imperial College in the United Kingdom, biomedical engineering program at the Technische University of the Netherlands and the aerospace engineering program at the Massachusetts Institute of Technology in the USA (Brodeur et al., 2002; Perrenet et al., 2000). There are many studies about the successful use of PBL approaches in engineering. For example, a study by Reeves and Laffey (1999) found that the PBL approach in engineering courses at the U.S. Air Force Academy has increased students' achievement and problem solving skills.

In the Malaysian context, there are a number of pilot projects carried out at such as the one at the University of Malaya, Said et al. (2005) has integrated the PBL approach in engineering courses. He has proposed that $20 \%$ of the course should use a PBL approach in the first year and increased to $90 \%$ in the final year of study. The conventional approach is maintained. The facilitators are responsible for bringing the students to the concept of "learning by doing". Facilitators should also be able to raise challenging questions, encourage and create a conducive learning environment. While Joseph et al. (2005) has integrated the PBL approach in the classroom environment at the University of Technology Malaysia using active learning techniques in the Process Control and Dynamic Course and was successful in increasing students' achievement and motivation. Ahmad and Jabbar (2007), however, have conducted a pilot study in the use of PBL approach for the computer engineering program at the University of Tun Hussein Onn Malaysia (UTHM) and this study has produced a rubric for the assessment of teaching and learning.

The PBL approach has already been used in many polytechnics and executed abroad (Tseng et al., 2011; Tseng et al., 2008). The study by O'Grady et al. (2012) using the PBL approach in the Singapore Polytechnic where the concept of "one-day, one-problem" was introduced to the students to develop innovative human capital, possess problem-solving skills and create a lifelong learning attitude. Huijser and Hasan (2012), reviewed the effectiveness 
of PBL in Bahrain polytechnic to enhance the graduates' employability and innovation skills. In the Malaysian context, a PBL model has been developed at the polytechnic in electrical engineering courses to enhance critical thinking and intrinsic motivation of students (Alias \& Sulaiman, 2012; Alias et al., 2011). On the other hand, Awang and Ramly (2008) used the PBL procedure to enhance the creative thinking of the polytechnic students in Structural Mechanics courses. Both of these studies are carried out face to face.

Although the PBL approach showed many advantages compared to conventional learning approach, but there are still some constraints that caused this approach to be less practiced such as; too many students in a class, the number teachers who are not skilled in using PBL approaches, a short period of T \& $\mathrm{L}$, problems in providing appropriate set of problems fitting the topics of learning, lack of resources and high operating costs (Farnsworth, 1994; Jamaluddin, 2004) and an educator should act as a facilitator and this is difficult to be done in the specified learning environment (Albion \& Gibson, 1998). In addition, the use of PBL problem scenarios is limited to text and oral formats (Hoffmann \& Ritchie, 1997), the difficulty in understanding PBL problems using traditional media (Albion \& Gibson, 1998; Zydney, 2005), lack of resources or materials and guidance for educators (Simons \& Klein, 2007), problems of group work (Farnsworth, 1994; Rice \& Wilson, 1999) as well as problems in the formation of the group (Van Berkel \& Dolmans, 2006). Ferreira and Trudel (2012) argue that technological developments can be more easily integrated with PBL approach. The combination of PBL and ICT approach is capable of replacing conventional PBL approach in the classes (Alias \& Solomon, 2012; Hsu et al., 2012; Park \& Park, 2012; Selvi et al., 2012; Watson \& Fang, 2012). Albion (2010) also proposed the use of interactive multimedia for presenting and displaying models to be used in the $\mathrm{T} \& \mathrm{~L}$ process, including in the field of engineering.

\section{The Online PBL Approach}

The widespread use of computers and the internet, gave a positive impact on the implementation of the PBL approach. This development got the attention of online learning materials development (Donnelly \& Fitzmaurice, 2005; McAlpine \& Allen, 2007). This was demonstrated in previous studies that supported the use of ICT in implementing PBL to facilitate access to data and information resources by developing collaborative learning laboratory for medical courses (Koschmann et al., 1996). The internet networking technology and websites are used to support the PBL collaboratively in bio-technology and physiotherapy courses (Donnelly \& Fitzmaurice, 2005; Poikela et al., 2007). Meanwhile, Albion (2000) developed interactive multimedia software titled Integrating Information Technology into Teaching of Information Technology subjects using a PBL approach. Lowther and Morrison (2003), developed the Integrating Technology for Inquiry (Nteq) software for Computer Science subjects using PBL. Hmelo-Silver et al. (2006) have developed the eSTEP system for trainee teachers to learn the concepts of science using videos in PBL. Savin-Baden and Gibbon (2006) developed the SONIC (Students Online in Nursing Integrated Curriculum) for nursing students using the PBL interactively to promote independent learning and investigation.

In the Malaysian context, Jamaluddin (2004) has developed a web-based learning system that uses a PBL approach to the topic of Multimedia Technology for 44 students in the third year of undergraduate studies, which managed to improve their performances in the test, increased their confidence and cognitive level. Meanwhile Faaizah (2008) examined the use of multimedia packages using PBL approach in the science subject of form two, in the topic of nutrition, to enhance students' achievement. On the other hand, Faridah (2009) examined the use of interactive multimedia software using a PBL approach for the mathematics topics set for form four students to raise their achievement and problem-solving skills. The study by Fauziah (2011) examined the use of Learning Management System by PBL approach to enhance critical and creative thinking of students in physics courses at university level.

In the engineering context, the study by Tseng et al. (2008) examined the use of online learning based on the PBL approach in vocational high schools in digital logic courses. His research found that students showed a positive attitude towards online learning. Meanwhile, Tseng et al. (2011), conducted a study for 8 weeks on high school students for the digital logic courses in Taiwan using the PBL web collaboratively to solve problems, found that the use of online PBL can improve students' attitudes and, the web usability aspects of the system showed the existence of a collaborative environment, interactive and comfortable.

In the context of polytechnics of Malaysia, Krishnan and Ruhizan (2009) have developed a website using a PBL approach for project courses for electrical engineering students to improve the quality of their products. In addition, Rahman et al. (2011) developed an e-Library and Learning Object System for project development courses for Mechanical courses at polytechnics. ICT development has also attracted the interest of many researchers to apply the PBL approach in web-based learning, particularly to support collaborative learning 
(Atan et al., 2005; Poikela et al., 2007). Donnelly and Fitzmaurice (2005) outlined a number of branches of the use of ICT to support learning in PBL such as presentation, problem discussion, reflection, collaboration, sharing of ideas, evaluation and administration of the whole learning. However, studies on the development of online learning materials and contents using a PBL approach in general and specifically for engineering students of polytechnic students still not well explored in Malaysia to enhance their knowledge and skills. Finally, it cannot be denied that the use of ICT in implementing PBL is important in acting as a catalyst for teaching and learning.

\section{The Models and Features of Online PBL}

There are various PBL models that have been developed by researchers and educators to achieve a specific objective. According to Faaizah (2008), the main purpose is to change students from being the passive recipients of information to active information processors. Indirectly, teaching methods also changed from teaching-oriented to learning-oriented. According to Wee (2004), the students have to go through seven levels of learning in PBL which begins with the formation of groups, understanding the problem, hypothesis construction, construction of learning issues, self-learning, presentation of problems and reflection. Meanwhile, Barrows (1986) indicated that students need to ask questions about the three things, namely: "what is interesting here? What is puzzling and what is important to find out?" to solve the given problem. Massa (2008) proposed the needed four levels in the PBL, which are: problem analysis, self-learning, developing ideas and testing the solution.

According to Faaizah (2008), the PBL approach begins with the presentation of a genuine problem and students in a small group will determine the next steps to find the solutions and present the problem's alternative solutions to the instructor for evaluation. There are various models or features in the context of PBL in Malaysia that was already adapted for online learning. Jamaluddin (2004) has combined the features of PBL (Bridges 1992; Caroline 1998) in designing the web-based learning materials for the students of teacher training college. Fauziah (2011) modified three PBL models, which are, the McMaster University model (Barrows \& Tamblyn 1980), Torp and Sage model (Torp \& Sage, 1998) and Pastirik model (2006) in designing the online learning materials for physics courses at university level. Atan et al. (2005) have adopted the Harper-Marinick PBL model (2001) in the design of online learning materials for the Physics courses. Faridah (2009) used the features of PBL such as authentic problem scenarios, inquiry process, the formation of the group and PBL techniques in the production of interactive multimedia courseware for the topics of form four students. Faaizah (2008) used the features of constructivism, the characteristics of PBL, collaboration features and contextual features in designing a multimedia package for the science (nutrition) subject of form two students.

\section{Conclusion}

However, the study on the development of online learning materials based on the PBL approach specifically for engineering students are still less explored in Malaysia in enhancing their knowledge and skills. This statement is supported by Brodie (2009) who stated that online PBL approach is poorly documented, especially in the engineering field. Furthermore, the study by Fauziah (2011) reported that there is a lack of online learning materials based on PBL approach in Malaysia and made several recommendations regarding the future development of online learning materials based on PBL approach (i) conduct researches in various levels and courses, (ii) develop the learning materials with more vivid and interesting PBL elements, (iii) design specific teaching methods to implement the elements of PBL in the process of teaching and learning in a more motivating and beneficial way for the students and facilitators. This statement is supported by Kim and Kee (2012), who stated that there is a lack of needed theoretical framework and engineering pedagogy and as well as the best method of online PBL implementation in designing and developing e-content materials based on PBL.

\section{References}

Ahmad, A., \& Jabbar, M. H. (2007). POPBL Experience: A First Attempt in First Year Electrical Engineering Students.

Albion, P. (2000). Interactive Multimedia Problem-Based Learning for Enhancing Pre-Service Teachers' Self-Efficacy Beliefs About Teaching with Computers: Design, Development and Evaluation. Tesis University of Southern Queensland.

Albion, P. (2010). Learning Recursively: Integrating PBL as an Authentic Problem Experience. Plenary Presentation.

Albion, P. R., \& Gibson, I. W. (1998). Interactive Multimedia and Problem-Based Learning. Challenges for Instructional Design.

Alias, M., \& Sulaiman, Y. (2012). The Impact of Instructional Methods on Critical Thinking: A Comparison of Problem-Based Learning and Conventional Approach in Engineering Education. ISRN Education 2012. 
Alias, M., Yamin, S., \& Aris, R. (2011). The Effect of Problem Based Learning on Students' Intrinsic Motivation in the Polytechnic's Electrical Engineering Course.

Atan, H., Sulaiman, F., \& Idrus, R. M. (2005). The Effectiveness of Problem-Based Learning in the Web-Based Environment for the Delivery of an Undergraduate Physics Course. International Education Journal, 6(4), 430-437.

Awang, H., \& Ramly, I. (2008). Creative Thinking Skill Approach through Problem-Based Learning: Pedagogy and Practice in the Engineering Classroom. International Journal of Human and Social Sciences, 3(1), $18-23$.

Barrows, H. S. (1986). A Taxonomy of Problem-Based Learning Methods. Medical education, 20(6), 481-486. http://dx.doi.org/10.1111/j.1365-2923.1986.tb01386.x

Barrows, H. S. (1996). Problem-Based Learning in Medicine and Beyond: A Brief Overview. New directions for teaching and learning, (68), 3-12. http://dx.doi.org/10.1002/t1.37219966804

Barrows, H. S., \& Tamblyn, R. M. (1980). Problem-Based Learning: An Approach to Medical Education. Springer Publishing Company.

Boud, D., \& Feletti, G. (1998). The Challenge of Problem-Based Learning. Routledge.

Bridges, E. M. (1992). Problem Based Learning for Administrators. ERIC.

Brodeur, D. R., Young, P. W., \& Blair, K. B. (2002). Problem-Based Learning in Aerospace Engineering Education.

Brodie, L. (2009). Eproblem-Based Learning: Problem-Based Learning Using Virtual Teams. European Journal of Engineering Education, 34(6), 497-509. http://dx.doi.org/10.1080/03043790902943868

Charlin, K. (1998). The Many Faces of Problem-Based Learning: A Framework for Understanding and Comparison. Medical Teacher, 20(4), 323-330. http://dx.doi.org/10.1080/01421599880742

Donnelly, R., \& Fitzmaurice, M. (2005). Collaborative Project based Learning and Problem-Based Learning in Higher Education: A Consideration of Tutor and Student Roles in Learner-Focused Strategies. Emerging Issues in the Practice of University Learning and Teaching. Dublin: AISHE.

Faaizah, S. (2008). Pakej Multimedia Sains (Nutrisi) Menggunakan Pendekatan Pembelajaran Berasaskan Masalah Secara Hibrid (C2hadam). Tesis Doktor Falsafah, Universiti Kebangsaan Malaysia.

Faridah, H. (2009). Perisian Kursus Multimedia Interaktif Untuk Mata Pelajaran Matematik (Topik Set) Menggunakan Pendekatan Pembelajaran Berasaskan Masalah (PBL Maths-Set). Tesis Doktor Falsafah, Universiti Kebangsaan Malaysia.

Farnsworth, C. C. (1994). Using Computer Simulations in Problem-Based Learning. Document Resume, 145.

Fauziah, S. (2011). The Effectiveness of Problem-Based Learning (PBL) Online on Students' Creative and Critical Thinking in Physics at Tertiary Level in Malaysia. Tesis. University of Waikato.

Ferreira, M. M., \& Trudel, A. R. (2012). The Impact of Problem-Based Learning (PBL) on Student Attitudes toward Science, Problem-Solving Skills, and Sense of Community in the Classroom. The Journal of Classroom Interaction, 47(1), 23-30.

Hassan, A., Ariffin, M., Mohd Yusof, K., Abd Hamid, M. K., Hassim, M. H., Abdul Aziz, A., Hassan, S., \& Helmi, S. A. (2004). A Review and Survey of Problem-Based Learning Application in Engineering Education.

Hmelo-Silver, C. E. (2004). Problem-Based Learning: What and How Do Students Learn? Educational Psychology Review, 16(3), 235-266. http://dx.doi.org/10.1023/B:EDPR.0000034022.16470.f3

Hmelo-Silver, C. E. (2012). International Perspectives on Problem-Based Learning: Contexts, Cultures, Challenges, and Adaptations. Interdisciplinary Journal of Problem-based Learning, 6(1), 3. http://dx.doi.org/10.1007/978-94-007-2515-7_1

Hmelo-Silver, C. E., \& Barrows, H. S. (2006). Goals and Strategies of a Problem-Based Learning Facilitator. Interdisciplinary Journal of Problem-based Learning, 1(1), 4. http://dx.doi.org/10.7771/1541-5015.1004

Hmelo-Silver, C. E., \& Eberbach, C. (2012). Learning Theories and Problem-Based Learning. Problem-Based Learning in Clinical Education, 3-17. http://dx.doi.org/10.1007/978-94-007-2515-7_1

Hoffmann, B., \& Ritchie, D. (1997). Using Multimedia to Overcome the Problems with Problem Based Learning. 
Instructional Science, 25(2), 97-115. http://dx.doi.org/10.1023/A:1002967414942

Hsu, C. K., Hwang, G. J., Chuang, C. W., \& Chang, C. K. (2012). Effects on Learners' Performance of Using Selected and Open Network Resources in a Problem-Based Learning Activity. British Journal of Educational Technology. http://dx.doi.org/10.1111/j.1467-8535.2011.01235.x

Huijser, H., \& Hasan, J. (2012). Working Towards Innovative Practitioners. Problem-Based Learning at Bahrain Polytechnic, 8-17.

Jamaluddin, H. (2004). Pembinaan Dan Penilaian Keberkesanan Sistem Pembelajaran Berasaskan Masalah Menerusi Web Bagi Program Perguruan. Tesis Doktor Falsafah, Universiti Teknologi Malaysia.

Kim, K. J., \& Kee, C. (2012). Evaluation of an e-PBL Model to Promote Individual Reasoning. Medical Teacher, $1-6$.

Koschmann, T., Kelson, A. C., Feltovich, P. J., \& Barrows, H. S. (1996). Computer-Supported Problem-Based Learning: A Principled Approach to the Use of Computers in Collaborative Learning. CSCL: Theory and practice of an emerging paradigm, 83-124.

Lowther, D. L., \& Morrison, G. R. (2003). Integrating Computers into the Problem-Solving Process. New directions for teaching and learning, (95), 33-38. http://dx.doi.org/10.1002/tl.110

Massa, N. M. (2008). Problem-Based Learning (PBL). Journal of Higher Education, 22(5), 19-20.

Mcalpine, I., \& Allen, B. (2007). Designing for Active Learning Online with Learning Design Templates.

Murray, I., \& Savin-Baden, M. (2000). Staff Development in Problem-Based Learning. Teaching in Higher Education, 5(1), 107-126. http://dx.doi.org/10.1080/135625100114993

O'grady, G., Yew, E. H. J., Goh, K. P. L., \& Schmidt, H. G. (2012). One-Day, One-Problem: An Approach to Problem-Based Learning. Springer. http://dx.doi.org/10.1007/978-981-4021-75-3

Park, K., \& Park, S. (2012). Development of Professional Engineers' Authentic Contexts in Blended Learning Environments. British Journal of Educational Technology, 43(1), E14-E18. http://dx.doi.org/10.1111/j.1467-8535.2011.01244.x

Pastirik, P. J. (2006). Using Problem-Based Learning in a Large Classroom. Nurse Education in Practice, 6(5), 261-267. http://dx.doi.org/10.1016/j.nepr.2006.02.003

Perrenet, J., Bouhuijs, P., \& Smits, J. (2000). The Suitability of Problem-Based Learning for Engineering Education: Theory and Practice. Teaching in Higher Education, 5(3), 345-358. http://dx.doi.org/10.1080/713699144

Poikela, S., Vuoskoski, P., \& Kärnä, M. (2007). International Problem-Based Learning Syposium. Singapore.

Rahman, M. B. B. H. A., Ismail, H. N., \& Daud, K. A. M. (2011). E-Library and Learning Object System (El-Los): An Alternative Online Library and Learning Tools at Politeknik Kota Bharu, Malaysia. International Journal of Business and Social Science, 2(2), 99-104.

Reeves, T. C., \& Laffey, J. M. (1999). Design, Assessment, and Evaluation of a Problem-Based Learning Environment in Undergraduate Engineering. Higher Education Research \& Development, 18(2), 219-232. http://dx.doi.org/10.1080/0729436990180205

Rice, M. L., \& Wilson, E. K. (1999). How Technology Aids Constructivism in the Social Studies Classroom. The Social Studies, 90(1), 28-33. http://dx.doi.org/10.1080/00377999909602388

Said, S., Adikan, F. R. M., Mekhilef, S., \& Rahim, N. A. (2005). Implementation of the Problem-Based Learning Approach in the Department of Electrical Engineering, University of Malaya. European Journal of Engineering Education, 30(1), 129-136. http://dx.doi.org/10.1080/03043790512331313895

Savin-Baden, M. (2000). Problem-Based Learning in Higher Education: Untold Stories. Society for Research into Higher Education.

Savin-Baden, M., \& Gibbon, C. (2006). Online Learning and Problem-Based Learning: Complementary or Colliding Approaches. Problem-based learning online, 126-139.

Sendag, S., \& Ferhan Odabasi, H. (2009). Effects of an Online Problem Based Learning Course on Content Knowledge Acquisition and Critical Thinking Skills. Computers \& Education, 53(1), 132-141. http://dx.doi.org/10.1016/j.compedu.2009.01.008

Simons, K. D., \& Klein, J. D. (2007). The Impact of Scaffolding and Student Achievement Levels in a 
Problem-Based Learning Environment. Instructional Science, $35(1), \quad 41-72$. http://dx.doi.org/10.1007/s11251-006-9002-5

Torp, L., \& Sage, S. (1998). Problems as Possibilities: Problem-Based Learning for K-12 Education. Association for Supervision \& Curriculum Development.

Tse, W., \& Chan, W. (2003). Application of Problem-Based Learning in an Engineering Course. International Journal of Engineering Education, 19(5), 747-753.

Tseng, K. H., Chiang, F. K., \& Hsu, W. H. (2008). Interactive Processes and Learning Attitudes in a Web-Based Problem-Based Learning (PBL) Platform. Computers in Human Behavior, 24(3), 940-955. http://dx.doi.org/10.1016/j.chb.2007.02.023

Tseng, K., Chang, C. C., \& Lou, S. J. (2011). The Process, Dialogues, and Attitudes of Vocational Engineering High School Students in a Web Problem-Based Learning (WPBL) System.

Van Berkel, H. J. M., \& Dolmans, D. H. J. M. (2006). The Influence of Tutoring Competencies on Problems, Group Functioning and Student Achievement in Problem-Based Learning. Medical education, 40(8), 730-736. http://dx.doi.org/10.1111/j.1365-2929.2006.02530.x

Watson, W. R., \& Fang, J. (2012). PBL as a Framework for Implementing Video Games in the Classroom. International Journal of Game-Based Learning, 2(1), 77-89. http://dx.doi.org/10.4018/ijgbl.2012010105

Wee, K. N. L. (2004). Jump Start Authentic Problem-Based Learning. Pearson/Prentice Hall.

Yusof, K. M., Tasir, Z., Harun, J., \& Helmi, S. A. (2005). Promoting Problem-Based Learning (PBL) in Engineering Courses at the Universiti Teknologi Malaysia. Global J. of Engng. Educ, 9(2), 175-184.

Zydney, J. M. (2005). Eighth-Grade Students Defining Complex Problems: The Effectiveness of Scaffolding in a Multimedia Program. Journal of Educational Multimedia and Hypermedia.

\section{Copyrights}

Copyright for this article is retained by the author(s), with first publication rights granted to the journal.

This is an open-access article distributed under the terms and conditions of the Creative Commons Attribution license (http://creativecommons.org/licenses/by/3.0/). 